\title{
Interactions of climate, socio-economics, and global mercury pollution in the North Water
}

\author{
Rune Dietz, Anders Mosbech, Janne Flora, Igor Eulaers
}

Published online: 7 March 2018

\begin{abstract}
Despite the remoteness of the North Water, Northwest Greenland, the local Inughuit population is affected by global anthropogenic pollution and climate change. Using a cross-disciplinary approach combining Mercury (Hg) analysis, catch information, and historical and anthropological perspectives, this article elucidates how the traditional diet is compromised by $\mathrm{Hg}$ pollution originating from lower latitudes. In a new approach we here show how the Inughuits in Avanersuaq are subject to high $\mathrm{Hg}$ exposure from the hunted traditional food, consisting of mainly marine seabirds and mammals. Violation of the provisional tolerably yearly intake of $\mathrm{Hg}$, on average by a factor of 11 (range 7-15) over the last 20 years as well as the provisional tolerably monthly intake by a factor of 6 (range 2-16), raises health concerns. The surplus of Selenium (Se) in wildlife tissues including narwhals showed Se:Hg molar ratios of 1.5, 2.3, and 16.7 in muscle, liver, and mattak, respectively, likely to provide some protection against the high $\mathrm{Hg}$ exposure.
\end{abstract}

Keywords Biomagnification · Human exposure ·

Mercury $\cdot$ North water $\cdot$ Risk assessment

\section{INTRODUCTION}

Mercury $(\mathrm{Hg})$ and in particular methyl-Hg biomagnifies and is present throughout the Arctic food chain, leaving high trophic marine avian and mammalian species with high body burdens ( Dietz et al. 1996; AMAP 1998). An estimated 200-300 tons of $\mathrm{Hg}$ are transported annually to

Electronic supplementary material The online version of this article (https://doi.org/10.1007/s13280-018-1033-z) contains supplementary material, which is available to authorized users. the Arctic by long-range atmospheric and oceanic processes and ocean currents from various anthropogenic activities at mid-latitudes, emphasizing the worldwide nature of $\mathrm{Hg}$ pollution (AMAP 1998, 2011; Berg et al. 2001; Lindberg et al. 2001; Lu et al. 2001). A recent focus on Integrating mercury research and policy in a changing world" has just been issued in a special section on mercury in Ambio addressing the extensive global problems and effects from use, emission, and global transport of $\mathrm{Hg}$ across the World (e.g., Chen and Driscoll 2018). Although $\mathrm{Hg}$ is a naturally occurring element, worldwide anthropogenic activity has led to a manifold increase of $\mathrm{Hg}$ in the Arctic environment compared to pre-industrial times (Dietz et al. 2006, 2009; Braune et al. 2011). Furthermore, Hg emissions are projected to further increase unless new pollution abatement technologies are applied to coal-fired power plants (Streets et al. 2009).

A review on the literature on ancient temporal trend studies revealed that $\mathrm{Hg}$ concentrations have increased almost 20-fold since the industrial beginning in 1850 (Dietz et al. 2009). These observations have been confirmed by an updated study on polar bears Ursus maritimus for the North Water Polynya (Pikialasorsuaq, hereafter referred to as NOW; Dietz et al. 2011). Studies on soft tissue consumed by the Arctic Inuit populations are, however, less clear. Rigét et al. (2011) applied a statistically robust method to 83 timeseries of $\mathrm{Hg}$ in Arctic biota collected over the past 2-3 decades. However, no consistent trend was evident across tissues and species from the circumpolar Arctic during the investigated period, most likely due to the fact that most time-series were too short to detect significant trends. There was, however, a tendency towards increasing $\mathrm{Hg}$ concentrations in marine species in Northern Canada and West Greenland compared to the North Atlantic Arctic. Though, data are too meagre to establish secure time trends for all 
consumed species in communities situated on both sides of the NOW, as well as other Arctic areas.

In addition to $\mathrm{Hg}$, an array of chlorinated, brominated, and fluorinated persistent organic pollutants (POPs) have been transported to the Arctic and have been studied with respect to their effects, geographical and temporal trends, and human exposure. The NOW is, however, not the highest exposed site for these contaminants, and are, therefore, not of particular interest in the present study (AMAP 1998, 2003, 2004, 2009, 2015; Dietz et al. 2013a, b; Letcher et al. 2010).

The awareness of the presence, environmental increase, and detrimental health effects of $\mathrm{Hg}$ has recently resulted in the Minamata Convention (2017), which intends to reduce the international production and use of $\mathrm{Hg}$. This convention is similar to the Stockholm Convention on POPs, which aims to eliminate or restrict the production and use of POPs and has, indeed, led to a decrease of the environmental impact of these contaminants in the Arctic (Dietz et al. 2013a, b; Rigét et al. 2013, 2015; Stockholm Convention 2017). An urgent need for international mitigation of $\mathrm{Hg}$ is called upon by the alarmingly high $\mathrm{Hg}$ concentrations in local inhabitants of the Avanersuaq region of Northwest Greenland facing the NOW. The observed concentrations exceed 5-50-fold that of other Arctic Inuit populations, including the Iñupiat, Yup'ik, Dene/Métis and other indigenous and non-indigenous Arctic populations (AMAP 1998, 2009). These studies also identify the Avanersuaq population, i.e., the Inughuit, to be the highest exposed population within Greenland. Therefore, we investigated the human exposure to $\mathrm{Hg}$ in Avanersuaq using a cross-disciplinary approach combining data on chemical contaminants, catch information, historical, and anthropological perspectives. We first aimed at elucidating to which degree the traditional food is being compromised by $\mathrm{Hg}$ pollution, and, second, how seasonal and inter-annual hunting and dietary patterns may be tied to a changing health risk.

\section{MATERIALS AND METHODS}

\section{Subsistence hunt and dietary choice}

The extensive amount of hunting data for a wide range of hunted species in the period 1993-2013 collected by the Ministry of Fisheries \& Hunting, Government of Greenland (Piniarneq 2015) was used in a new approach to calculate the amount of $\mathrm{Hg}$ entering monthly and annually the hunting societies around the NOW. The average meat outcome per species was on average estimated at $30 \%$ of the average total weight of the hunted species. We hence used this as a crude estimate of ingested meat from the hunted species obtained from the Piniarneq database, which does not hold information on size, age, and sex of the hunted individuals, known to have an effect of the weight of the hunted wildlife. Only meat was used in the exposure models as the majority of the other edible parts, i.e., the majority of blubber, lungs, spleen, liver, kidneys, and intestines, are consumed by the sled dogs. The introduction of quotas and seasonal hunting regulations, as well as new fishing opportunities and hunting limitations from climate related unfavourable ice and weather conditions, means that the hunting statistics summarizes more than the animals' presence in the area, but also reflects complex changes over time. Demographic data on population size, sled dog numbers, trade, economic, and occupational data were obtained from Greenland Statistics (2017) for Avanersuaq, and the periods were dependent on the available data and questions discussed. In addition to this, interviews and general anthropological conversations with the local population contributed to the general picture described below. Ethnographic fieldwork concerning the local distribution and symbolic, cultural, and monetary values attached to food was carried out in during 2014-2016 primarily in Qaanaaq and Savissivik using participant observation and unstructured interviews.

\section{Mercury exposure}

Data on meat $\mathrm{Hg}$ concentrations were not available for each species or year during the 20-year period spanning 1993-2013. The Hg data set used in the present study was, therefore, either extracted from published literature or analysed from freshly collected meat, i.e., muscle samples conducted under the NOW project. The chemical analysis for $\mathrm{Hg}$ followed previously reported methods of element extraction (Søndergaard et al. 2011; Sonne et al. 2014). Each muscle sample was freeze-dried and homogenized, while the remaining tissues were analysed as such. For each sample, the dry weight content was gravimetrically determined and a subsample was subjected to microwave digestion in $8 \mathrm{~mL}$ of a $\mathrm{HNO}_{3}$ :MilliQ water mixture $(1: 1$, $v: v)$. The digested solutions were diluted with MilliQ water and analysed for a wide range of trace elements, though only $\mathrm{Hg}$ data are employed within the present study. An Agilent 7900 CE ICP-MS was used for quantification at the accredited trace element laboratory of the Department of Bioscience of the Aarhus University, Denmark.

Temporal trend analyses of the hunted game over time were performed using R (R Core Team 2016). Prior to the statistical analyses, individual hunted numbers were logtransformed to obtain normality and homoscedasticity of the variance. To test for temporal trends, linear regression analyses were applied using individual log-transformed hunted wildlife numbers as the dependent variable and year as the explanatory variable (e.g. Dietz et al. 2004, 2011).

The yearly average Inughuit $\mathrm{Hg}$ exposure, expressed per gram meat $(\mathrm{g})$, as a result of the hunted game in Avanersuaq 
over time was calculated by combining data on average meat intake from the hunt from 1993 to 2013 (Piniarneq 2015; Electronic Supplementary Material, Table S2) with data on average meat $\mathrm{Hg}$ concentrations taken from published and unpublished contaminant studies in Northwest Greenland (Fig. 1; Table S3, S4). To link the yearly $\mathrm{Hg}$ intake to guideline values, the Provisional Tolerably Yearly Hg Intake (PTYI) and the Provisional Tolerably Monthly Hg Intake (PTMI) for the community, assuming an average individual body weight of $60 \mathrm{~kg}$, were calculated according to the following (US Environmental Protection Agency 1997):

PTYI $=\mathrm{Hg}(\mathrm{g}) \times 52$ weeks $\times$ population number

and

$\mathrm{PTMI}=\mathrm{Hg}(\mathrm{g}) \times 4$ weeks $\times$ population number

for which the mean Inughuit population size is 849 , varying from 795 to 881 between 1993 and 2013.

\section{RESULTS AND DISCUSSION}

\section{Long-term changes in the hunt, diet, and $\mathrm{Hg}$ exposure}

Between 1993 and 2013, hunters in Avanersuaq caught an average of 27925 animals each year (Fig. S1, Table S1). In absolute numbers, the top five (in declining order) are composed of little auk Alle alle (Fig. 2; 22599 individuals or 81\%), ringed seal Pusa hispida (Fig. 3; 2704 individuals or $10 \%$ ), Brünnich's guillemot Uria lomvia (1200 individuals or 4\%), Arctic hare Lepus arcticus (287 individuals or 1\%), and bearded seal Erignathus barbatus (178 individuals or $1 \%$; Table S1). Considering meat to be on average $30 \%$ of a mammal's mass, these hunting numbers amount to an estimated $287 \mathrm{t}$ in total meat consumed (Table S4). Moreover, roughly, a similar amount of blubber, liver, kidney, heart, and intestines is estimated to be consumed by the hunters' sled dogs. From a mass perspective, the yearly input of meat is mostly composed of ringed seal $(27 \mathrm{t})$, followed by narwhal Monodon monoceros (Figs. 4, 5; 19 t), walrus Odobenus rosmarus $(15 \mathrm{t})$, bearded seal $(9 \mathrm{t})$, and beluga Delphinapterus leucas (3 t) (Fig. 1; Table S2).

For most of the species, the hunt shows yearly fluctuations without any noticeable trends over the data period. However, the catch percentage of walrus, beluga, Arctic hare, little auk, common guillemot Uria aalge, common eider Somateria mollissima and black-legged kittiwake Rissa tridactyla dropped significantly by $4-11 \%$ year $^{-1}$ over the past 2 decades, while the catch percentage of muskox Ovibus moschatus, caribou Rangifer tarandus, and harp seal Pagophilus groenlandicus increased significantly by $8-14 \%$ year $^{-1}$ (Figs. 1, S1, S2).

There is quite a large difference in personal preference for what part of the animal body is consumed, depending on the area of Avanersuaq, the season, the species, the hunter, and,

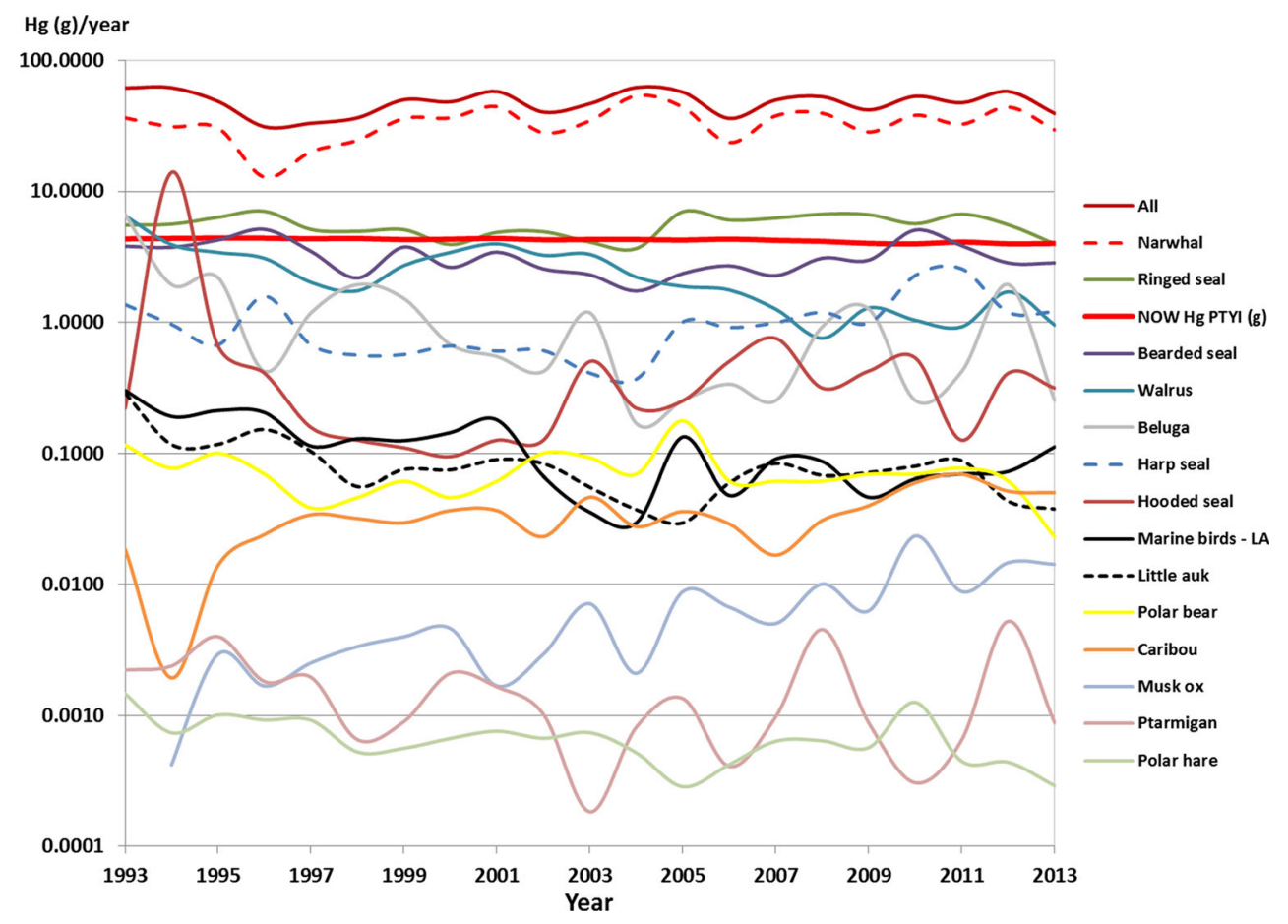

Fig. 1 Temporal Hg load in the hunted game of Avanersuaq based on average hunt from 1993 to 2013 (Piniarneq 2015) and average Hg loads in muscle tissue from the published and unpublished contaminant studies in Greenland (see Table S3 for details) 


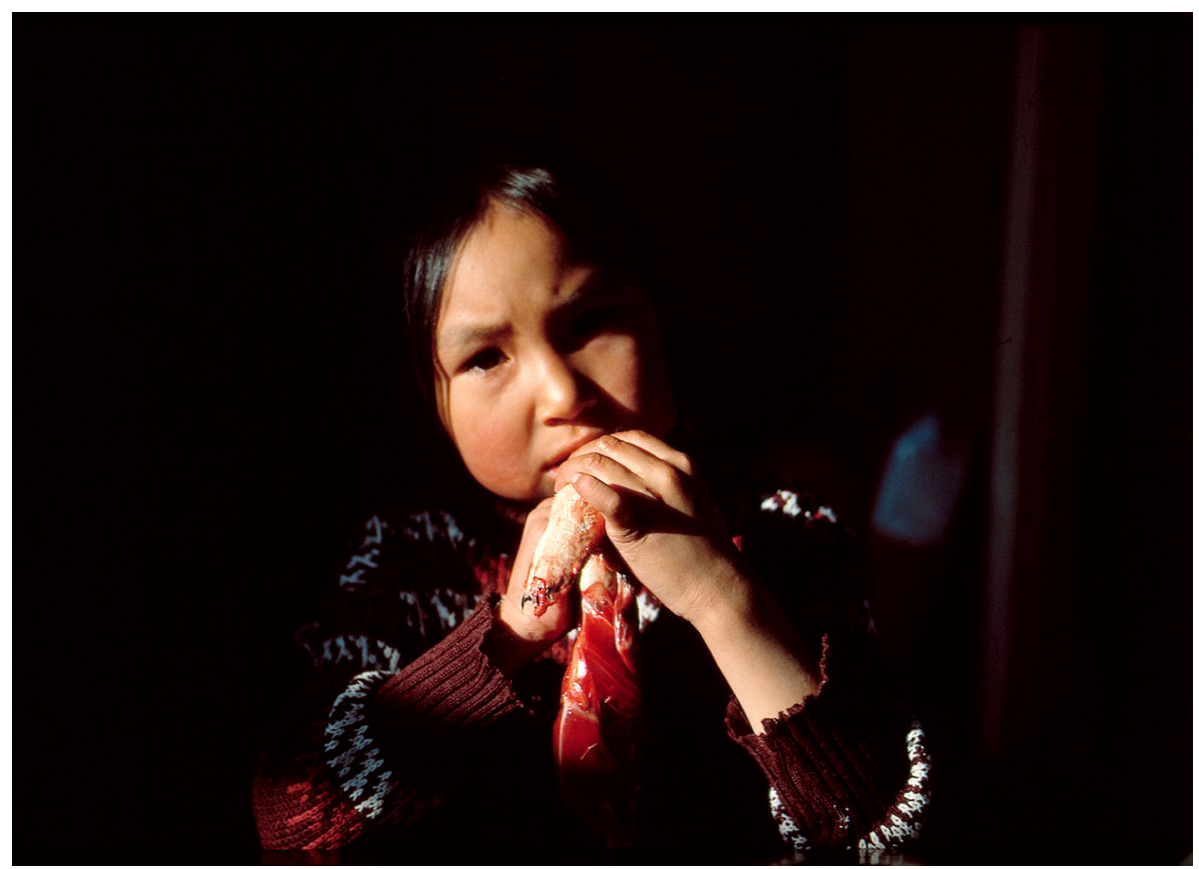

Fig. 2 Little auks are the most numerous birds eaten, but due to their small size, they range as number 10 in importance as food resources in the North Water (Photo: Rune Dietz)

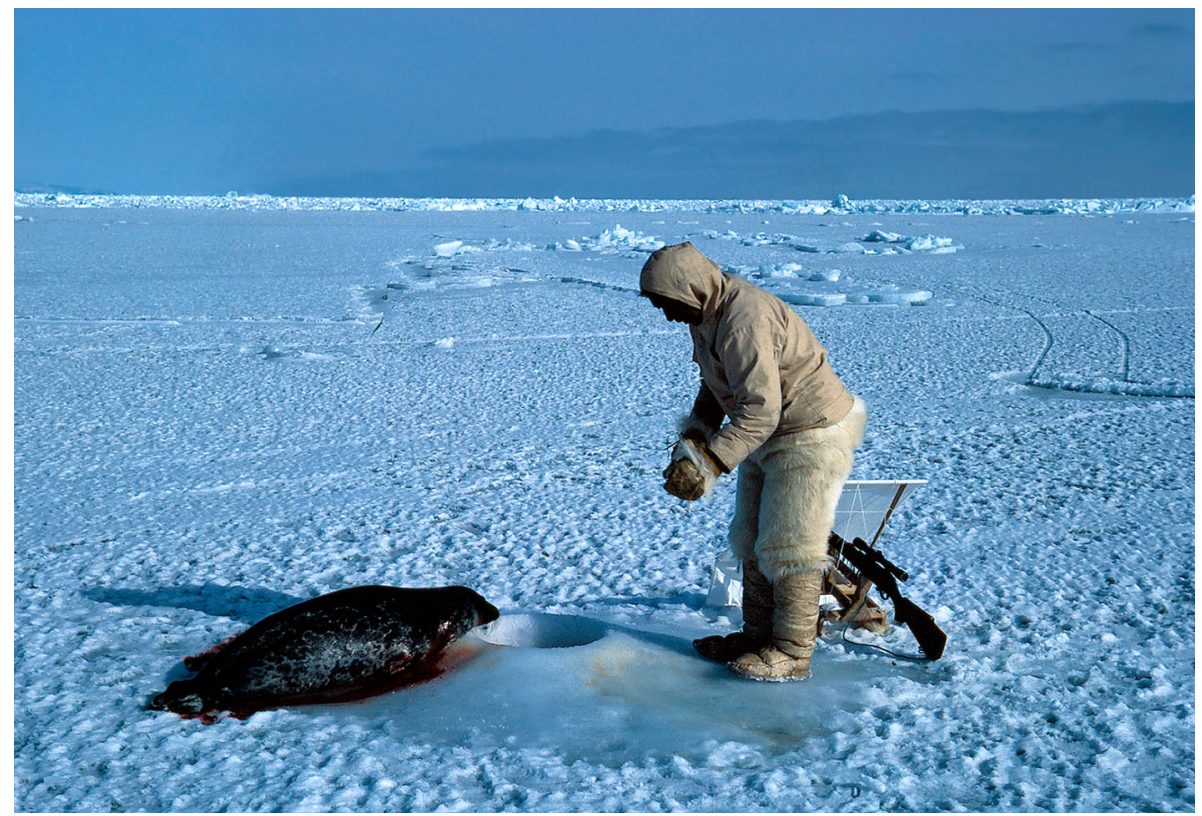

Fig. 3 Ringed seals are one of the most important food resources in the North Water as it is present and can be hunted year-round (Photo: Rune Dietz)

of course, the occasion. Conversations with the local population indicate that certain organs such as liver and kidney may be less popular than they used to be, and that it is primarily the older generations who continue to eat these at the present day. We do note, however, that some local specialities have organs as their central ingredients, and these tend to be eaten by most. Some species such as bearded seal and polar bear Ursus maritimus liver are, however, never consumed due to their toxic vitamin A load.

It is well documented that the majority of $\mathrm{Hg}$ in meat is present as methyl-Hg (Dietz et al. 1990; Wagemann et al. 1998), a Hg species readily (95\%) taken up over the intestinal 


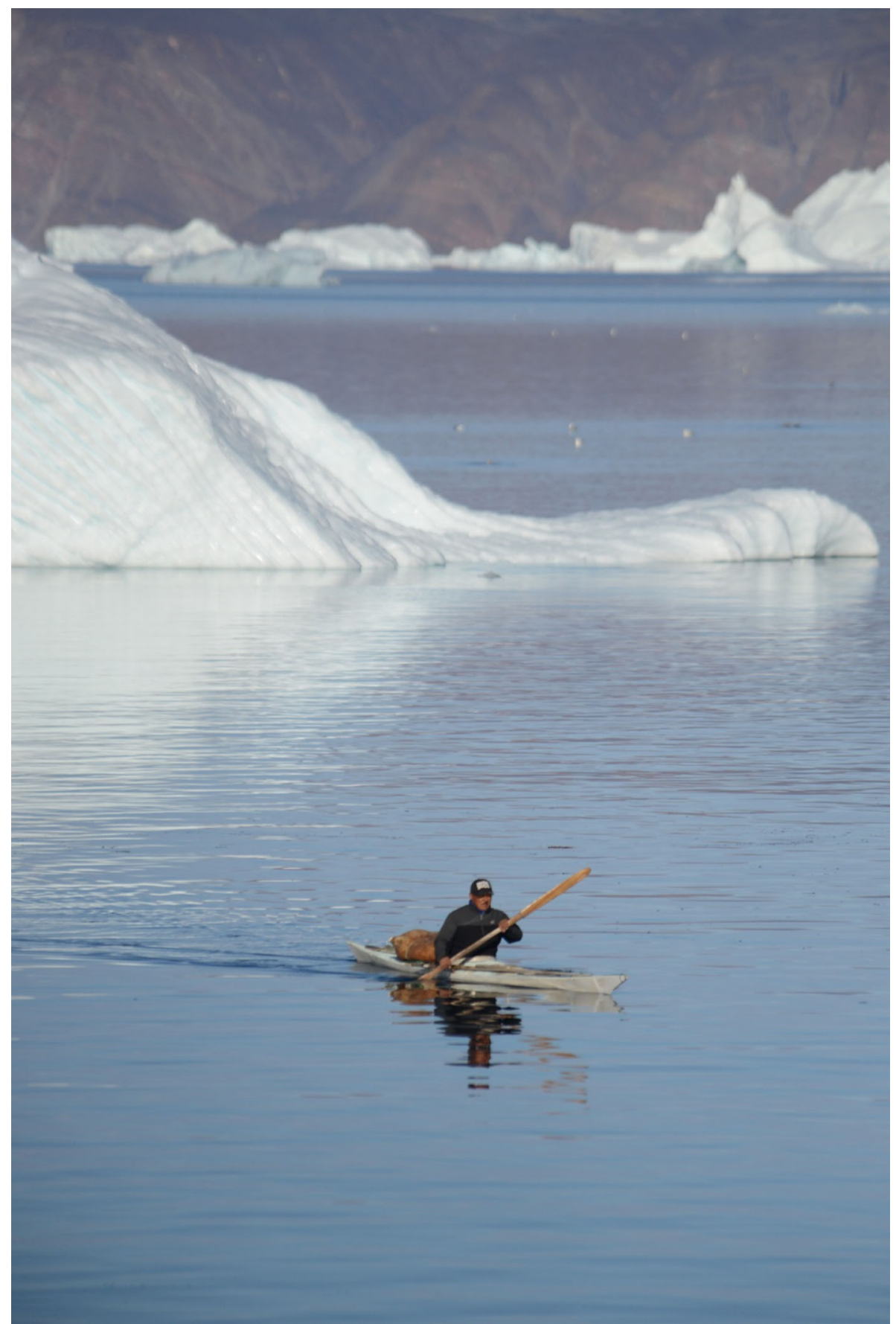

Fig. 4 Narwhals hunted in Avanersuaq are hunted from kajak, where the whales are harpuned prior to being shot. This traditional hunting method results in practically no hunting loss (Photo: Rune Dietz)

wall and, therefore, toxic to mammals (Berlin 1986; WHO 1993; Mori et al. 2012; Dietz et al. 2013c). Hence, meat represents the primary source of human $\mathrm{Hg}$ exposure associated to consumption of wildlife, representing up to $70 \%$ of the $\mathrm{Hg}$ taken in by consumption of various tissues including liver, kidney, heart, intestine, and blubber (Dietz et al. 2017).
With the estimated average yearly influx of $46 \mathrm{~g} \mathrm{Hg}$ year $^{-1}$ (range: $33-62 \mathrm{~g} \mathrm{Hg} \mathrm{year}^{-1}$ ), the PTYI was on average exceeded by a factor of 11 -fold (range: $7-15$ fold; Table S4). This transgression would be even higher if other tissues from these marine mammals and birds, from fish, and from other non-recorded items had been included. 

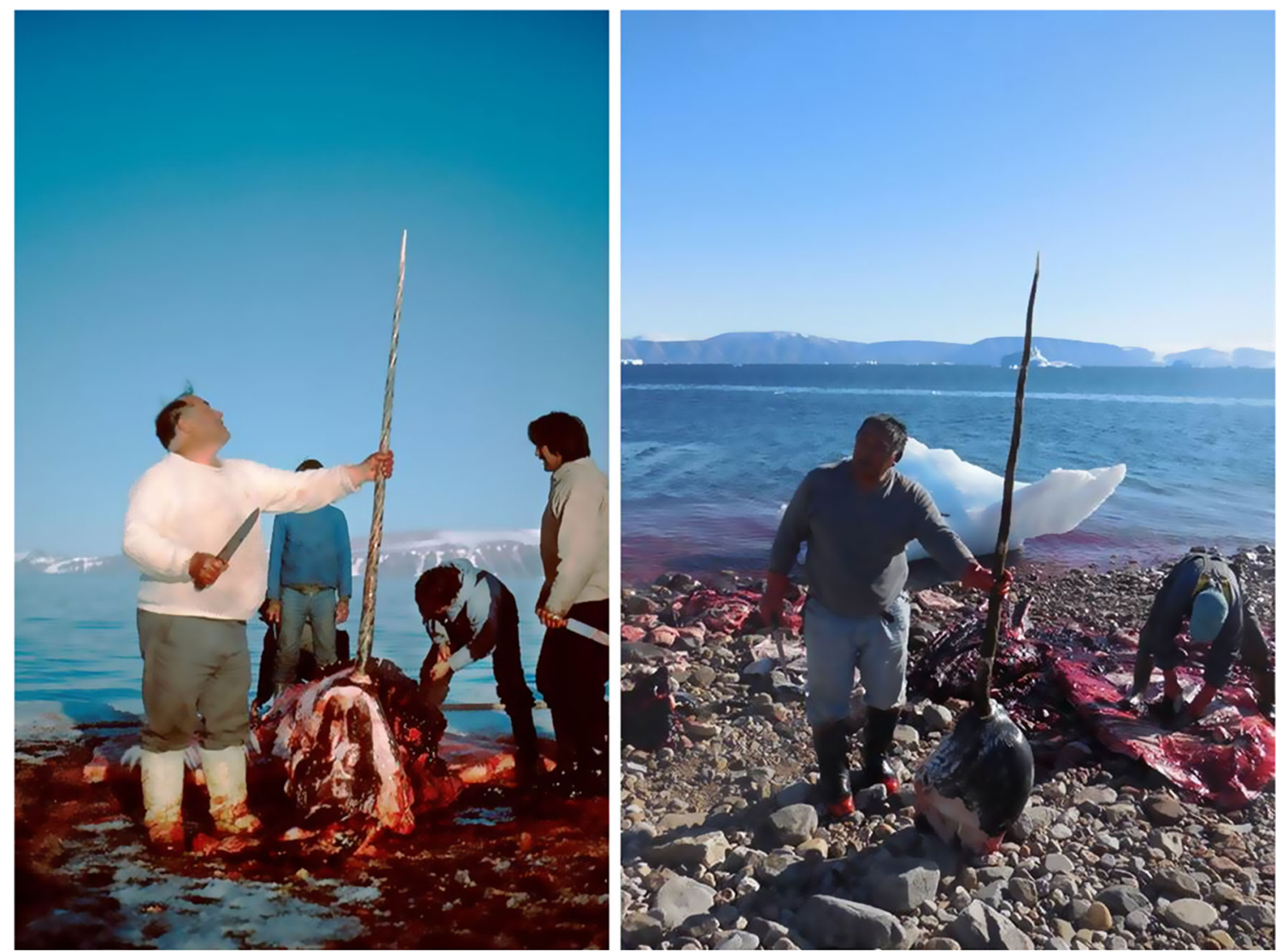

Fig. 5 In addition to the meat and mattak, narwhals are hunted for there valuable tusks. The two pictures were taken 31 years apart. To the left, Massauna Kristiansen is looking at the tusk, while his sons are flensing the narwhal caught in June 1984. To the right, the son Mamarut Kristiansen is engaged in narwhal hunting following the methods learned from his farther in August 2015 (Photos: Rune Dietz)

\section{Seasonal changes in the hunt, diet, and Hg exposure}

The marked seasonal environmental variation, represented by the extent of land fast ice, impacts also the presence and accessibility of animals (see also Flora et al. 2018). During autumn and winter, most birds will migrate southwards, which also applies to harp and hooded seals, the majority of narwhals and belugas, as well as baleen whales (Vibe 1950; Heide-Jørgensen et al. 2003; Dietz et al. 2008; Andersen et al. 2009; CAFF 2013; Grønnow 2016). From the hunt numbers reported by Piniarneq 2015, it becomes evident that the major $\mathrm{Hg}$ influx occurs during the 5 months from June to October, during which narwhals are present in the region and are the dominant caught species (73\%). Their presence essentially drives this seasonally peaking influx of $\mathrm{Hg}$ into the Inughuit population as the majority of the meat is eaten fresh and only minor proportion is dried or frozen (Fig. 6, Table S1). Hence, hunted food is mainly eaten at the season when it becomes available as it provides a welcomed variation in the food intake. Actually what characterises the so-called "hunter-gatherer cultures" is that they do not have food storage in the same way that agricultural societies do. Nor is it the case that Inughuit preserve food "for the long and dark winter". Hunting and fishing for human and $\operatorname{dog}$ consumption continue throughout the year. Although Inuit throughout the Arctic do have varying ways of preserving food for the most part dried meat and fish, frozen or fermented, are treated as light delicacy meals usually consumed at special celebrating occasions. Hence, the estimated average seasonal monthly influx of $2.1 \mathrm{~g} \mathrm{Hg}$ month $^{-1}$ (range: $0.53-5.2 \mathrm{~g} \mathrm{Hg}$ month ${ }^{-1}$ ) resulting from the hunted and consumed wildlife meat results in the PTMI on average to be exceeded by a factor of 7-fold (range: 2-16 fold; Fig. 6; Table S5). This seasonal pattern is supported by a pilot study on seasonal exposure of the Inughuit population based on weekly samples of facial hair from local inhabitants with different occupation and from different parts of Avanersuaq (Dietz et al. 2017). These results likewise show a higher load during summer, beginning to increase in June and peaking in August-September after which the exposure declines due to reduced narwhal consumption and consequent $\mathrm{Hg}$ excretion. One of the occupational hunters analysed showed up to 100-times larger $\mathrm{Hg}$ concentrations than reference persons, transgressing up to 45-times the US 


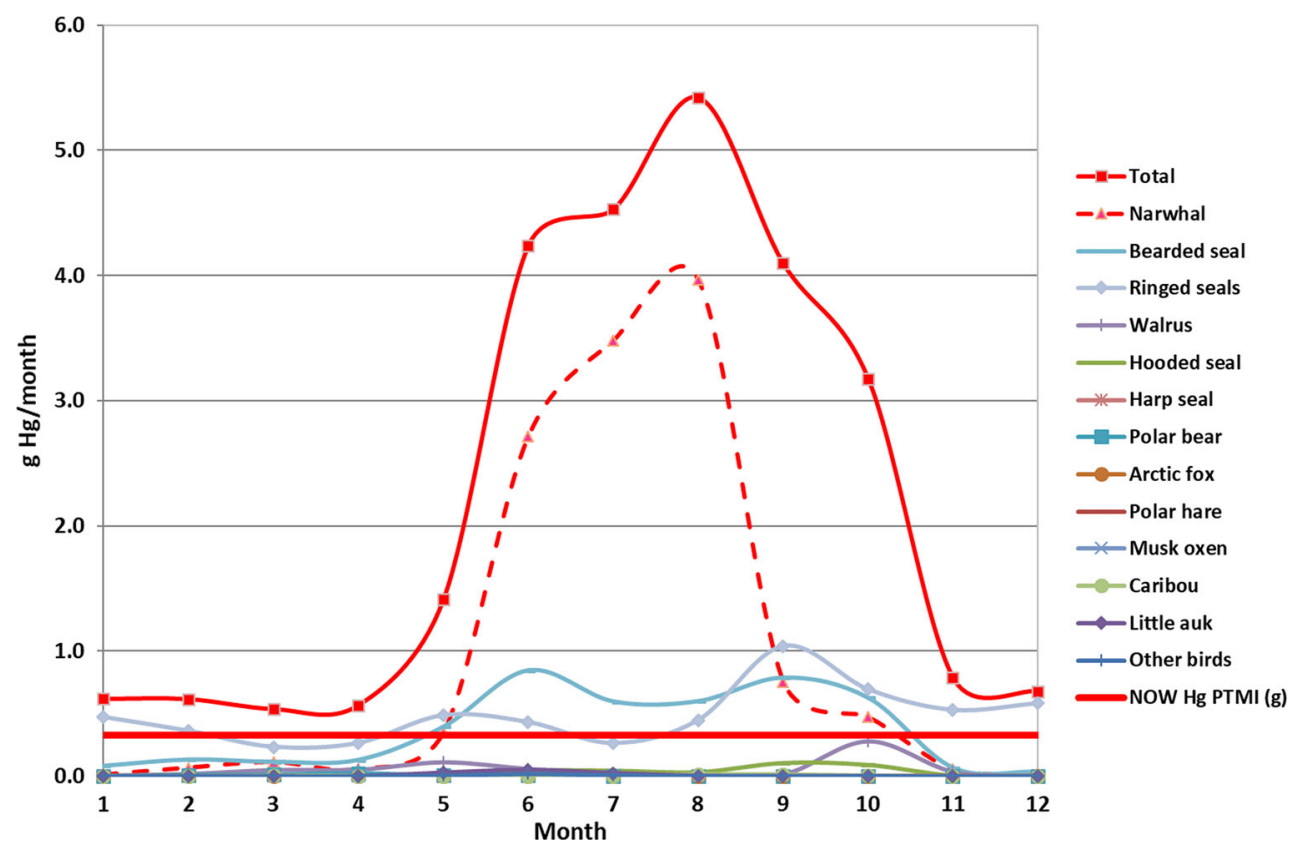

Fig. 6 Seasonal Hg load in the hunted game of Avanersuaq based on average hunt from 1994 to 2014 (Piniarneq 2015) and average Hg loads in muscle tissue from the present study and published and unpublished contaminant studies in Greenland (see Table S5 for details)

Environmental Protection Agency guideline value for acceptable $\mathrm{Hg}$ concentration in human hair.

The above meat-orientated estimate alone is certainly an underestimation of the exposure to the hunters as also blubber, and for a part of the population also liver, kidney, and intestine are being consumed. As the yearly amount of meat on average totals around $86 \mathrm{t}$ over the last 2 decades, the total edible part of the wildlife (edible non-meat likewise composes ca. 30\%), including the meat influx, is likely closer to $172 \mathrm{t}$ year $^{-1}$. However, a substantial amount is also needed for feeding sled dogs (see discussion below). How much local food is eaten per hunter per day is uncertain as the literature values range from a rather low estimate of $169 \mathrm{~g} \mathrm{day}^{-1}$ (calculated for the entire Greenland; $n=2245$ between 2005 and 2008) to a rather high estimate of $943 \mathrm{~g} \mathrm{day}^{-1}$ (for the Belcher Island region for 1995-1996; Wein et al. 1996; Jeppesen et al. 2012). We estimate the average daily intake for Avanersuaq to be close to $500 \mathrm{~g} \mathrm{day}^{-1}$ and would lead to a yearly wildlife demand of $155 \mathrm{t} \mathrm{year}^{-1}$ for the average Inuight population (Fig. 7). This is considerable more than our estimate of meat intake, estimated at $80 \mathrm{t}$, resulting from the wildlife hunt.

The fulltime hunters in Avanersuaq have some 1016 sledge dogs to feed (Greenland Statistics 2017). However, the number of sled dogs has been declining all over Greenland including Avanersuaq, partly due to less favourable ice conditions and longer open water seasons, and perhaps more crucially, owing to the fact that the number of occupational hunters is in decline (Fig. 8). In
Avanersuaq, the sled dog numbers have significantly declined by $1.4 \%$ per year since 1993 with an average reduction of 39 dogs per year between $1990(n=1800)$ and $2016(n=1036)$, which is similar to the overall trend in Greenland where the decline has been $1.5 \%$ per year (Greenland Statistics 2017; Fig. S3). As the total volume of catch has not overall changed significantly, the reduction in the number of dogs is likely to increase the amount of food available for human consumption as the hunters have fewer dogs to feed. Dogs are fed different feeds and amounts, depending on the season and the intensity with which they have worked. According to Gerth et al. (2010), Greenland dogs are fed every second day or third day with seal, walrus, or whale meat during summer with a meal size of $1-2 \mathrm{~kg}$ meat per dog. In winter, these dogs receive melted and heated chunks of seal or walrus meat plus internal organs and tissue every other day (approx. meal size of $2 \mathrm{~kg}$ per $\mathrm{dog}$ ). Only during hunting trips in winter, additional food may be provided to the dogs. A sled dog, therefore, consumes approximately $519 \mathrm{~kg}$ food per year (Gerth et al. 2010) which is slightly more than our estimates based on conversations with the local hunters. Hence, using an average of $500 \mathrm{~kg}$ per dog per year, the provisions for the 1036 dogs in the entire region amounts to as much as 518 $\mathrm{t}_{\text {year }}{ }^{-1}$. However, many hunters also buy food pellets in the local shop to secure provisions. Unfortunately, information on the amount of imported food over the time period dealt with in the present study was not available.

Another factor that may affect the amount of local food available to the community is how much of the game is 


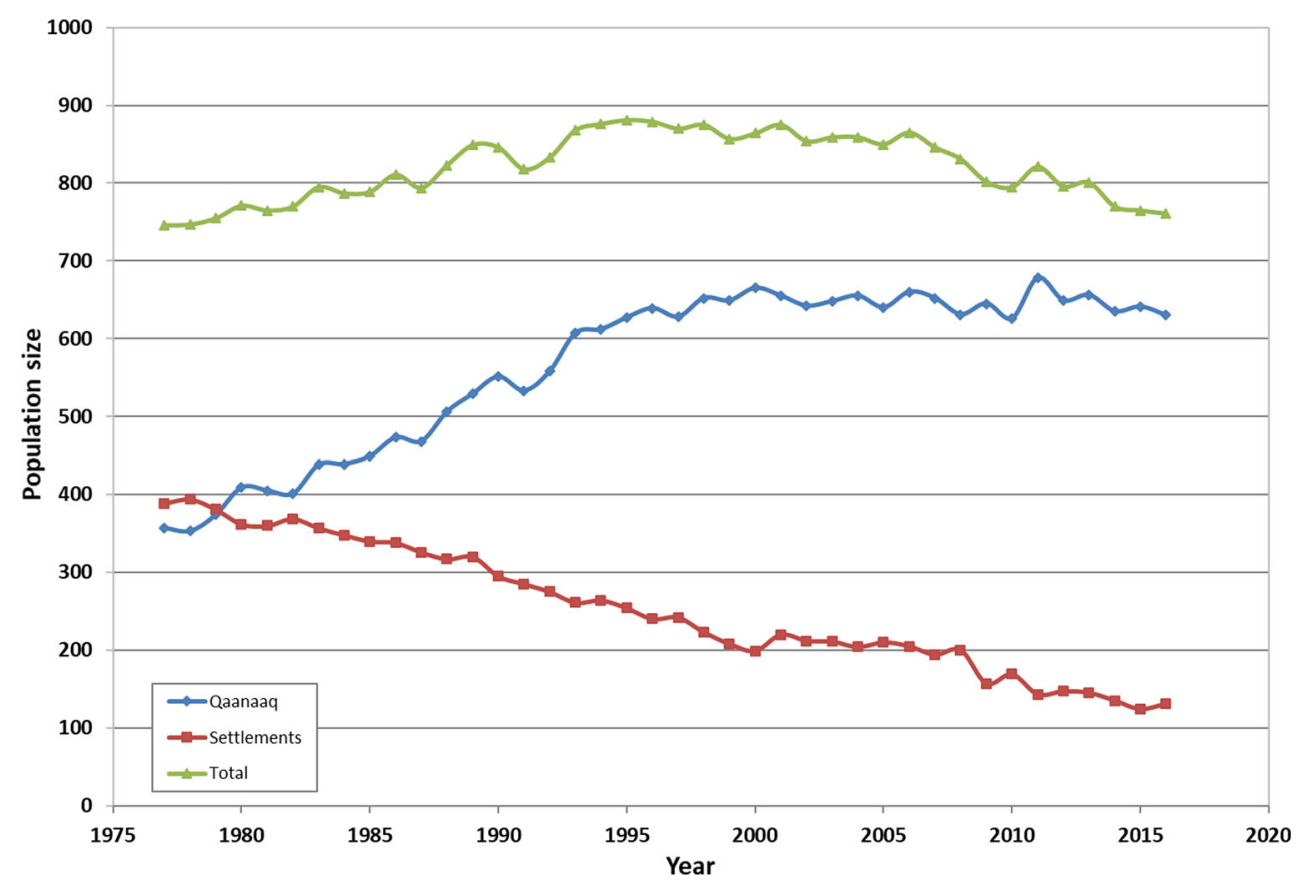

Fig. 7 Qaanaaq human population over the last 4 decades presented for Qaanaaq versus settlements (Greenland Statistics 2017)

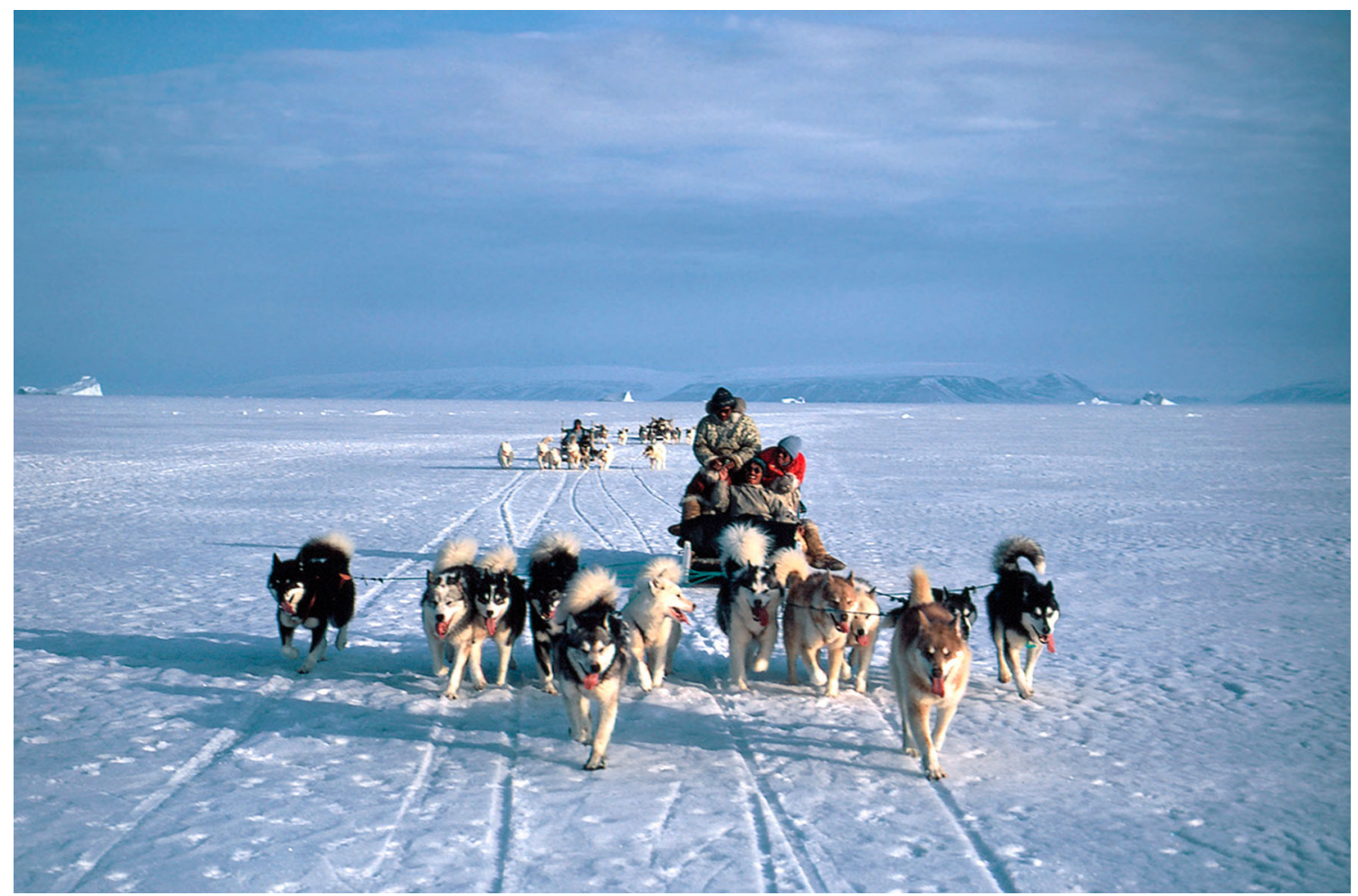

Fig. 8 Dog sledge is and important during the winter hunt. However, the sled dog numbers have been declining all over Greenland including Avanersuaq due to less favourable ice conditions, longer open water seasons and the fact that the number of occupational hunters itself is in decline (Photo: Rune Dietz) 


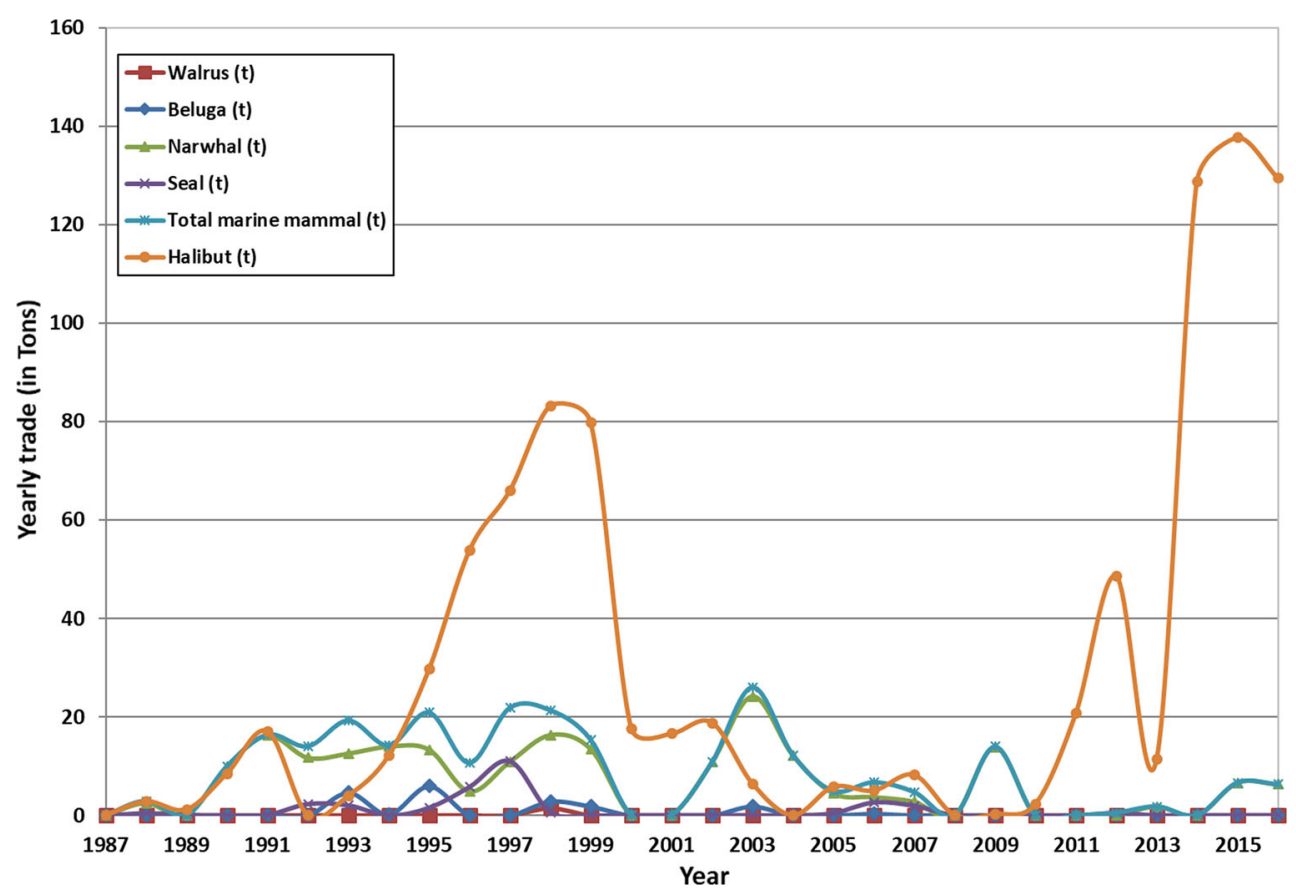

Fig. 9 Yearly trade of wildlife and Greenland halibut fishery (in tons) to Inughuit Seafood and Royal Greenland in Qaanaaq over the last 3 decades (Greenland Statistics 2017)

being traded into Royal Greenland and Inughuit Seafood in Qaanaaq established in 2014. Today, the mainstay trade is Greenland halibut Reinhardtius hippoglossoides. For marine mammal species, amounts vary substantially from year to year, while, on average, some $8.7 \mathrm{t}$ are traded in per year over the period 1987-2016; Greenland Statistics 2017). Historically, the majority of this amount relates to narwhal products $(81 \%)$, unspecified seal meat, not traded since $2007(11 \%)$, and beluga products $(6.8 \%)$, whereas walrus meat constitutes less than $0.6 \%$ owing to the relatively small quota and its main use to feed dogs (Fig. 9). As the majority of the narwhal and beluga products $(88 \%$ or $7.7 \mathrm{t}$ year $^{-1}$ ) are their skin (mattak) which in itself has not a high $\mathrm{Hg}$ or POP load in contrast to the attached blubber (Dietz et al. 2004). This trade, therefore, reduces the healthy consumption of this important mattak resource.

Adding up the demand of the community (154 t year ${ }^{-1}$ ) and their dogs $\left(515 \mathrm{t} \mathrm{year}^{-1}\right)$, the total demand amounts to some $669 \mathrm{t} \mathrm{year}^{-1}$, which is approximately fourfold our estimated local catch of $172 \mathrm{t}_{\text {year }}{ }^{-1}$. In addition to the game hunt, bird eggs are being collected but even with some 2000 eggs collected from different birds such as glaucous gull Larus hyperboreus and little auk this most likely amounts to less than $0.2 \mathrm{t} \mathrm{year}^{-1}$. On top of hunted catch, fisheries for Arctic char Salvelinus alpinus and sculpin Myoxocephalus spp. have always been common though may only be in the magnitude of $1.0 \mathrm{t} \mathrm{year}^{-1}$. However, during recent years, fishing has become increasingly important and long-line fishery for Greenland halibut has become a significant resource assuring $130 \mathrm{t}$ of trade with Royal Greenland and Inughuit Seafood (Fig. 1). Sources of cash income have, indeed, changed in significant ways over the past decades (Flora et al. 2018; Hastrup et al. 2018). The cost of living is high, and with the hunting endeavour, itself being costly, the restrictions on the trade in by-products like tusks, furs, and to some extent seal skin have made the halibut a welcome source of income. The amounts of additional halibut as well as other fish species like Atlantic wolfish Anarhichas lupus, polar cod Boreogadus saida, spotted wolffish Anarhichas minor, Atlantic cod Gadus morhua, and redfish Sebastes marinus for private consumption is limited as they are not common or prized, and therefore, a little effort is allocated to such fishery. However, an estimate from hunter and municipality politician Jens Danielsen (pers. comm.) some additional $20 \mathrm{t}$ may be realistic. The discrepancy between meat and fish derived food and the food demand are most likely due to a substantial consumption of imported food, an underreporting in the hunting statistics, an overestimate of the food demand of both humans and dogs, or a combination of these factors.

\section{Human exposure and food security}

It is beyond the scope of this paper to summarize the human health effects of $\mathrm{Hg}$ as this is an extensive research area for medical doctors. Extensive human health assessments have though been reviewed under the Arctic 
Monitoring and Assessment Programme (AMAP) over the last 2 decades (AMAP 1998, 2003, 2009, 2015). Overall studies have generally shown associations with cardiac autonomic neuropathy indicating effects on the nervous system, whereas there have not been shown effects of $\mathrm{Hg}$ exposure or conflicting effects on blood pressure, cardiovascular diseases, and diabetes that pose severe threats elsewhere in the World (AMAP 2015; Larsen 2017). Over the recent years, there has been a growing recognition on taking genetic information into account when evaluating susceptibility to Hg-related health effects and various diseases, including fatty acid metabolism (AMAP 2015; Larsen 2017). Climate change is regularly seen to pose a threat to all of the World Health Organization's three pillars of food security, namely, (1) the access to food, (2) the availability of food, and (3) food use, which relates to the harvesting, sharing and consumption of local foods (Paci et al. 2004; Wesche and Chan 2010). These are unique to the Arctic region in such a way that we may be able to speak of cultural food security (Power 2008). Narwhal is one of the foods in Avanersuaq that is hunted and shared in accordance with particular prescriptions, and is, therefore, intimately connected to human relatedness. Normally hunting and sharing narwhal are important for human kinship and relatedness. However, the contamination of food highlights a different aspect of food security relating to risk and safety. In Avanersuaq, it is not that foods are not available, nor that people cannot access these, but rather that food (understood broadly) is engulfed by boundless global uncertainties and safety issues through the risk of contamination (Hastrup et al. 2016). This applies to local and imported foods alike.

The presence of $\mathrm{Hg}$ and other biomagnifiable contaminants in marine mammals is an issue that has been widely discussed with varying intensity in Greenland for decades. It is generally seen as a product of global pollution that intrudes local staple foods and puts the health of local populations at risk. These debates are counterbalanced by other findings that obesity and other life style illnesses play a greater role in adverse health outcomes than exposure to contaminants (Bjerregaard and Mulvad 2012). These findings are echoed locally in Avanersuaq, where (as in the rest of Greenland) shop-bought foods or Danish foods (Qallunaamernit) are regularly juxtaposed to local foods (Kalaalimernit) in terms of physical and psychological health. We should note, however, that determining how people locally understand and act in terms of safe and healthy food categories is not a straightforward matter of local versus imported. Each are at different times embraced and rejected. Either way, the contamination and safe consumption of food is a problem of both global and local magnitude. It comes from the outside and seeps through food and the health of the population (Hastrup et al. 2016).
In Qaanaaq, people are not blind to the fact that illnesses like obesity, diabetes, and cancer never used to be issues in the past, and that there may be a causal link between these illnesses, and the food people consume. Food safety and the human exposure to contaminants thus extends far beyond the $\mathrm{Hg}$ concentrations in marine mammals, and should be understood as connected (in cause and effect) to other issues relating to contamination, health, and food, including hunting practices, social relations, and societal subsistence.

Dietary preferences in Avanersuaq vary not only according to the seasons or when animals are hunted, but also among households and individuals. People here, as elsewhere, have different strategies for dealing with the risks related to food consumption. Some prefer to eat foods that have been harvested locally, while others may prefer shop-bought food. For some, food consumption is not a matter of choice, but of necessity and financial means. Some families cannot afford to shop for food, while others, who are in closely knit hunting families, cannot afford to purchase locally sourced foods as frequently as they may like to. Food security and safety, therefore, is also entwined with economy. In Denmark, food consumers handle foodrelated risks (additives, pesticides, growth hormones, etc.) in socially and politically complex ways (Halkier 2004). Some Danish consumers keep themselves informed and adapt their food preferences accordingly; others interchangeably ignore and adhere to health warnings in frustrated perplexity, while many assume a casual approach to food risks citing feasibility and pragmatism. What is necessary, safe, and preferred, is far from a universal matter. Many understood the Bovine spongiform encephalopathy crisis in Great Britain to be a health issue and, therefore, avoided British beef, while others regarded it a political vendetta against the British farmers and economy, and prioritised British beef over any other. A similar complexity is present among people in Avanersuaq, where the discourses about contamination of food interweave with notions of locality, freshness, and nutrition. What is regarded as nutritious 1 day may be regarded as contaminated the next, and people's food choices thus relate as much to matters of health and what is preferred, as they do to what is feasible and available. Sometimes, contaminants are suspected to be prevalent in local foods, but the nature and frequency of the contamination is unknown. Other times certain foods are fiercely avoided, because people consider them to be contaminated due to observations of individual animals with strange growths or unusual appearances. In conversation, one occupational hunter stated that he deeply desired more information about how pollution was affecting his livelihood, i.e., local foods. Others, including the same hunter, also maintain that it is not the local foods that are unhealthy, but rather the poor 
quality of imported foods, which are anonymous in origin as well as ingredients, or, indeed, the mix between local foods and shop-bought foods. These foods, delicious as they may be, are commonly seen to lack nutrition and lack the capacity to satisfy hunger.

The way in which contamination seeps varies greatly. One example relates to the events by which a kiviaq that had been consumed in the village Siorapaluk in July 2013, tragically claimed the lives of two people. These examples remind the hunters of the fact that food can be poisoness as a result combination airtight conditions of a plastic bag together with natural occurring bacteria. Another three persons were rescued by a medical team flown in from Nuuk administrating trivalent antitoxin and mechanical intubated ventilation. The accident was understood to be caused by foodborne botulism (Hammer et al. 2015), arisen from the technique of fermenting little auks in seal blubber inside a tightly stitched sealskin and later stored in a plastic bag. Some tend to blame the fermentation practice alone, deeming it dangerous. Locally, however, the kiviaq is not unanimously understood to have claimed human lives due to the failure of an age-old practice; nor even the fact, that this particular kiviaq had been made, by thick-billed murres or eiders, which are significantly larger than the little auk and, therefore, require longer fermentation time. Rather, many locals continue to maintain, that the culprit was the plastic bag, which had been used to store the birds after the kiviaq had been opened; chemicals having seeped into the fermented birds. According to Hammer et al. (2015) foodborne botulism results from ingestion of toxin-contaminated food, the toxin being produced in an environment allowing the anaerobic, Gram-positive bacterium Clostridium botulinum, to grow, facilitated by anaerobic conditions in a plastic bag with low concentrations of salt, sugar, and acid. According to the literature outbreaks of botulism have previously been reported among the Inuit populations of Alaska, Canada, and Greenland (Miller 1975; Sørensen et al. 1993; Loutfy et al. 2003; Leth 2014). The tension between the explanatory frameworks is more than a noticeable, one attributing the food technique and knowledge itself in combination with the airtight conditions of a plastic bag, while the other places the contamination beyond the food itself, in a plastic bag that invisibly seeps toxins into age-old life sustaining food traditions. Food contamination may also be seen as firmly anchored within a particular locality, although also having arrived from the outside in form of the B52 bomber carrying four hydrogen bombs that crash landed at the Thule Air Base in 1968. Elderly Qaanaaq residents today, who witnessed the landing and accidentally inhaled smoke from the fire, ascribe their ailments and illnesses to these events. Today, some hunters refuse to hunt in Wolfstenholme Fjord (Uummannap Kangerlua), asserting that food from here is contaminated and damaging to health. Others continue to hunt in these fjords as they always have. A report into the health status in Avanersuaq (Bjerregaard and Dahl-Petersen 2010) prompted by the fact that the population expressed concern about the comparatively high occurrence of terminal illness, which they interpreted as caused by plutonium entering the food chain. The report concluded that neither the rate of death nor cancer (nor other Plutonium related illnesses) could be shown to be higher in Avanersuaq than in other parts of Greenland. Nor could the study show any marked difference in the concentration of POPs in the blood between the population in Avanersuaq and the rest of Greenland. What is crucial here then is the local concern about contamination and the overall associated health status, the rate of which the local self-assessment showed to be higher than in other parts of Greenland, thus underscores the notion of uncertainty that runs through food safety issues. The concentration of $\mathrm{Hg}$ in the blood among the participants, however, was found to be considerably higher than in the rest of Greenland. The report links this to the high consumption of marine mammals, narwhals especially (Bjerregaard and Dahl-Petersen 2010).

What is qualified locally as contaminated or safe is at one and the same time concrete and blurred, both in terms of how the contamination manifests, and in terms of how people orient themselves accordingly. The intake of $\mathrm{Hg}$ is marked by seasonal variations that go hand in hand with the migration of animals and hunting patterns. $\mathrm{Hg}$ concentration can, therefore, scarcely be said to be constant or universal, neither in narwhals, nor in humans. Instead, these will vary as hunters and their families orient themselves towards different resources in the hunting calendar. Although some may recognise the high levels of $\mathrm{Hg}$ present in narwhal itself, its mattak is widely recognised as a food source that contains some of the most vital vitamins and minerals that make human life and survival possible in this part of the world.

\section{Mercury and selenium exposure}

A strong positive relation between the concentrations of $\mathrm{Hg}$ and Selenium (Se) in tissues of many fish-eating wildlife species, especially predatory marine mammals, is well documented (Koeman et al. 1975). The $\mathrm{Hg}-\mathrm{Se}$ relationship is a toxicant-nutrient interaction that has relevance for both basic biology and environmental risk assessment. High trophic level mammals and birds may be partially protected against $\mathrm{MeHg}$ toxicity due to chelation of inorganic $\mathrm{Hg}$ with $\mathrm{Se}$ in an approximate 1:1 molar ratio, respectively (Dietz et al. 2000a, 2013c). Hg and Se molar relationships in muscle, liver, and kidney tissue have been surveyed for a large number of Greenland marine animal species, showing that in a majority of the investigated individuals, Se was 
present in a molar surplus to $\mathrm{Hg}$. A similar surplus of $\mathrm{Se}$ was found in recently collected narwhal tissues from the region in 2015, where $\mathrm{Se}: \mathrm{Hg}$ molar ratios of $1.5,2.3$, and 17 were found for muscle, liver, and mattak, respectively. A 1:1 molar ratio was found in tissues of marine mammals with high $\mathrm{Hg}$ concentrations (above approx. $10 \mathrm{nmol} \mathrm{g}^{-1}$ ) in Greenland (AMAP 1998; Dietz et al. 1990, 1998, 2000a, b). These findings again support that $\mathrm{MeHg}$ is detoxified by a chemically inert $\mathrm{Hg}-\mathrm{Se}$ (tiemanite) complex found in marine mammals (Koeman et al. 1975; Scheuhammer et al. 1998, 2008; Woshner et al. 2001a, b, 2008; O'Hara and Becker 2003; Ikemoto et al. 2005). The large surplus of Se in many wildlife tissues including the narwhal mattak is hence likely to protect the Inughuit against their high $\mathrm{Hg}$ exposure. A large proportion of the mattak is, however, being traded to Royal Greenland and Inughuit Fisheries and exported to the capital and larger Greenlandic towns, where mattak is not as readily available from the local hunt.

A substantial amount of information on the healthy nutrients, fatty acids, and vitamins is available, but a thorough description on these themes would remove the focus on the $\mathrm{Hg}$ issue of this article. The AMAP (2009) Human Health Assessment hence concluded and confirmed the 'Arctic Dilemma' described first in the second AMAP assessment of human health in the Arctic (AMAP 2003) that: "Traditional food is nutritionally, culturally, economically, and spiritually important but is also the major source of exposure to POPs and metals. Nevertheless, the results of this assessment support the importance of promoting the consumption of traditional food after providing information which allows informed choice."

\section{CONCLUSION AND PERSPECTIVES FOR THE FUTURE OF THE NORTH WATER}

The previous ways of evaluating temporal contaminant trends in Arctic wildlife and Inuit food items have focused on monitoring with regular time intervals a few "essential" species of ecological importance to the hunting communities. In addition, several studies on geographical and temporal contaminant trends have been conducted on the Inuit populations across the Arctic (AMAP 2003, 2009, 2015). However, the present study has, for the first time, estimated seasonal and long-term temporal change of $\mathrm{Hg}$ entering an Arctic community, i.e., Avanersuaq, based on a 20-year record of hunting trends as well as evaluation of the $\mathrm{Hg}$ content in a large number of important hunted foods. The results of this study detect the main sources of $\mathrm{Hg}$ from the hunt, of which the narwhal meat are the most important, and reveals a number of climate related as well as cultural and socio-economic changes affecting the invisible threat of $\mathrm{Hg}$ exposure in Inuit populations. This study add evidence to that longrange transport of $\mathrm{Hg}$ in even a remote hunting society like the Inughuit in Avanersuaq are heavily affected by anthropogenic processes from the industrialized part of the world. The food chain biomagnification of $\mathrm{Hg}$ renders marine top predators, being important food items for the NOW Inuit population, ultimate sinks of $\mathrm{Hg}$ amplify the effects of $\mathrm{Hg}$ from southern latitudes. However, the marine food has beneficial nutritional aspects as it is also rich in vitamins, micronutrients, fatty acids, and Se, which is particularly true for mattak. In fact, Se is likely an antagonistic mechanism reducing the toxic impact of $\mathrm{Hg}$. Nonetheless, dietary advice in Greenland can reduce the exposure to $\mathrm{Hg}$, and as such, the Greenland Board of Nutrition is tasked with providing balanced information to the public about contaminants in traditional marine food items and general information about a healthy and nutritious diet. Pregnant and nursing women, as well as children and young people are encouraged to continue to eat the traditional marine food but to avoid or reduce consumption of older seals, toothed whales, seabirds, and polar bear, due to high concentrations of contaminants. Supplementary hunt oriented towards more terrestrial animals and increased fishing on lower trophic species has the potential of reducing human exposure to $\mathrm{Hg}$. Similar dietary advice is already given in other (sub)Arctic areas including Canada and the Faroe Islands, where consumption of marine mammals is also traditional. Finally, the Minamata Convention has recently entered into force, partly prompted by the documentation of high $\mathrm{Hg}$ concentrations within the Arctic marine ecosystem and hunting societies. It is the hope that it will facilitate a reduction of long-range transport of $\mathrm{Hg}$ into the Arctic similar to what has been achieved with the Stockholm Convention on POPs (Minamata Convention 2017; Stockholm Convention 2017).

\section{Recommendations}

The calculated estimated $\mathrm{Hg}$ exposures should be verified by linking individual hunting success to the $\mathrm{Hg}$ exposure monitored in blood and hair in future programs. In addition, longitudinal health studies of $\mathrm{Hg}$ and human geneenvironment studies in Greenland are still lacking. Finally, information on seasonal variation in human exposure should be taken into account when conducting geographical comparisons across the Arctic.

Acknowledgements We gratefully acknowledge the Velux Foundations and the Carlsberg Foundation for funding The North Water Project (NOW). Greenland Home Rule Government 2015 is likewise acknowledged for collecting and making the hunting data of the Piniarneq available to the present study. Greenland Statistics also provided extracts on the sled dogs in addition to the available 
information from their website. Colleagues across the countries who collected and previously published the data, which we used in the present calculation of $\mathrm{Hg}$ input and risk assessment, are likewise acknowledged. Thanks are owed to inhabitants in Avanersuaq, for their generous hospitality and willingness to participate in various research projects over the years. Finally, we would also like to acknowledge the large number of colleagues and local hunters who conducted tissue sampling in the region over the years.

Open Access This article is distributed under the terms of the Creative Commons Attribution 4.0 International License (http:// creativecommons.org/licenses/by/4.0/), which permits unrestricted use, distribution, and reproduction in any medium, provided you give appropriate credit to the original author(s) and the source, provide a link to the Creative Commons license, and indicate if changes were made.

\section{REFERENCES}

AMAP. 1998. AMAP Assessment 1998: Arctic Pollution Issues. Oslo: Arctic Monitoring and Assessment Programme (AMAP).

AMAP. 2003. AMAP Assessment 2002: Human Health in the Arctic. Oslo: Arctic Monitoring and Assessment Programme (AMAP).

AMAP. 2004. AMAP Assessment 2002: Persistent Organic Pollutants in the Arctic. Oslo: Arctic Monitoring and Assessment Programme (AMAP).

AMAP. 2009. AMAP Assessment 2009: Human Health in the Arctic. Oslo: Arctic Monitoring and Assessment Programme (AMAP).

AMAP. 2011. AMAP Assessment 2011: Mercury in the Arctic. Oslo: Arctic Monitoring and Assessment Programme (AMAP).

AMAP. 2015. AMAP Assessment 2015: Human Health in the Arctic. Oslo: Arctic Monitoring and Assessment Programme (AMAP).

Andersen, J.M., Y.F. Wiersma, G. Stenson, M.O. Hammil, and A. Rosing-Asvid. 2009. Movement Patterns of Hooded Seals (Cystophora cristata) in the Northwest Atlantic Ocean During the Post-Moult and Pre-Breed Seasons. Journal of Northwest Atlantic Fisheries Science 42: 1-11.

Berg, T., J. Bartnicki, J. Munthe, H. Lattila, J. Hrehoruk, and A. Mazur. 2001. Atmospheric Mercury Species in the European Arctic: Measurements and Modelling. Atmosperic Environment 35: 2569-2582.

Berlin, M. 1986. Mercury. In Handbook on the Toxicology of Metals, ed. L. Friberg, G.F. Nordberg, and V.B. Vouk, 387-435. Amsterdam: Elsevier Science Publishers.

Bjerregaard, P., and I.K. Dahl-Petersen. 2010. Sundhedsundersøgelsen in Avanersuaq 2010., Grønlandskrifter 23 Denmark: Statens Institut for Folkesundhed.

Bjerregaard, P., and G. Mulvad. 2012. The Best of Two Worlds: How the Greenland Board of Nutrition has Handled Conflicting Evidence About Diet and Health. International Journal of Circumpolar Health 71: 18588.

Braune, B., J. Carrie, R. Dietz, M. Evans, A. Garden, N. Gantner, J. Hedman, K. Hobson, et al. 2011. Are Mercury Levels in Arctic Biota Increasing or Decreasing, and Why? In AMAP Assessment 2011: Mercury, ed. P. Outridge, and R. Dietz, 85-112. Oslo: Arctic Monitoring and Assessment Programme (AMAP).

CAFF. 2013. Arctic Biodiversity Assessment. Status and Trends in Arctic biodiversity. Akureyri: Conservation of Arctic Flora and Fauna.

Chen, C.Y., and C.T. Driscoll. 2018. Integrating mercury research and policy in a changing world. Ambio 47: 111-115. https://doi.org/ 10.1007/s13280-017-1010-y.
Dietz, R., C. Overgaard Nielsen, M. Munk Hansen, and C.T. Hansen. 1990. Organic Mercury in Greenland Birds and Mammals. Science of the Total Environment 95: 41-51.

Dietz, R., F.F. Rigét, and P. Johansen. 1996. Lead, Cadmium, Mercury and Selenium in Greenland Marine Animals. Science of the Total Environment 186: 67-93.

Dietz, R., P. Paludan-Müller, C.T. Agger, and C. Overgaard Nielsen. 1998. Cadmium, Mercury, Zinc and Selenium in Ringed Seals (Phoca hispida) from Greenland and Svalbard. NAMMCO Scientific Contributions 1: 242-273.

Dietz, R., F.F. Rigét, and E.W. Born. 2000a. An Assessment of Selenium to Mercury in Greenland Marine Animals. The Science of the Total Environment 245: 15-24.

Dietz, R., F.F. Rigét, and E.W. Born. 2000b. Geographical Differences of Zinc, Cadmium, Mercury and Selenium in Polar Bears (Ursus maritimus) from Greenland. Science of the Total Environment 245: 25-48.

Dietz, R., F. Riget, K. Hobson, M.P. Heide-Jørgensen, P. Møller, M. Cleemann, J. de Boer, and M. Glacius. 2004. Regional and Inter Annual Patterns of Heavy Metals, Organochlorines and Stable Isotopes in Narwhals (Monodon monoceros) from West Greenland. Science of the Total Environment 331: 83-105.

Dietz, R., F.F. Rigét, E.W. Born, C. Sonne, P. Grandjean, M. Kirkegaard, M.T. Olsen, G. Asmund, et al. 2006. Trends in Mercury in Hair from Greenland Polar Bears (Ursus maritimus) during 1892-2001. Environmental Science and Technology 40: $1120-1125$.

Dietz, R., P.M. Outridge, and K.A. Hobson. 2009. Anthropogenic Contribution to Mercury Levels in Present-Day Arctic Animals-A Review. Science of the Total Environment 407: 6120-6131.

Dietz, R., M.P. Heide-Jørgensen, P. Richard, J. Orr, K. Laidre, and H.C. Schmidt. 2008. Movements of Narwhals (Monodon monoceros) from Admiralty Inlet Monitored by Satellite Telemetry. Polar Biology 31: 1295-1306.

Dietz, R., E.W. Born, F.F. Rigét, A. Aubail, C. Sonne, R.C. Drimmei, and N. Basu. 2011. Temporal Trends and Future Predictions of Mercury Concentrations in Northwest Greenland Polar Bear (Ursus maritimus) Hair. Environmental Science and Technology 45: $1458-1465$.

Dietz, R., F.F. Rigét, C. Sonne, E.W. Born, T. Bechshøft, M.A. McKinney, and R.J. Letcher. 2013a. Part 1: Three Decades (1984-2010) of Legacy Contaminant Trends in East Greenland Polar Bears (Ursus maritimus). Environment International 59: 485-493.

Dietz, R., F.F. Rigét, C. Sonne, E.W. Born, T. Bechshøft, M.A. McKinney, R. Drimmei, D.C.G. Muir, and R.J. Letcher. 2013b. Part 2: Three Decades (1984-2010) of Flame Retardant Trends in East Greenland Polar Bears (Ursus maritimus). Environment International 59: 494-500.

Dietz, R., C. Sonne, N. Basu, B.M. Braune, T. O’Hara, R.J. Letcher, T. Scheuhammer, M. Andersen, C. Andreasen, D. Andriashek, and G. Asmund. 2013c. What are the Toxicological Effects of Mercury in Arctic Biota? Science of the Total Environment 443: $775-790$.

Dietz, R., A. Mosbech, and I. Eulaers. 2017. Fangstdyr ved Nordvandet og den globale kviksølvforurening. Tidsskriftet Grønland 1: 26-36.

Flora, J., K.L. Johansen, B. Grønnow, A.O. Andersen, and A. Mosbech. 2018. Present and past dynamics of Inughuit resource spaces. Ambio. https://doi.org/10.1007/s13280-018-1039-6.

Gerth, N., P. Redman, J. Speakman, S. Jackson, and J.M. Starck. 2010. Energy Metabolism of Inuit Sled Dogs. Journal of Comparative Physiology 180: 577-589.

Greenland Statistics. 2017. http://www.stat.gl/default.asp?lang=da. 
Grønnow, B. 2016. Living at a High Arctic Polynya: Inughuit Settlement and Subsistence Around the North Water during the Thule Station Period, 1910-53. Arctic 69: 1-15. https://doi.org/ $10.14430 / \operatorname{arctic} 4573$.

Halkier, B. 2004. Handling Food-Related Risks: Political Agency and Governmentality. In The Politics of Food, ed. M.E. Lien, and B. Nerlich. London: Berg.

Hammer, T.H., S. Jespersen, J. Kantrup, V.C. Ballegaard, A. Kjerulf, and A. Gelvan. 2015. Fatal Outbreak of Botulism in Greenland. Infectious Diseases 47: 190-194.

Hastrup, K., A.M. Rieffestahl, and A. Olsen. 2016. Food Security: Health and Environmental Concerns in the North. In $A$ Companion to the Anthropology of Environmental Health, ed. M. Singer. New Jersey: Wiley.

Hastrup, K., A.O. Andersen, B. Grønnow, and M.P. Heide-Jørgensen. 2018. Life around the North Water ecosystem: Natural and social drivers of change over a millennium. Ambio. https://doi.org/10. 1007/s13280-018-1028-9.

Heide-Jørgensen, M.P., P. Richard, R. Dietz, K.L. Laidre, and J. Orr. 2003. An Estimate of the Fraction of Belugas (Delphinapterus leucas) in the Canadian High Arctic that Winter in West Greenland. Polar Biology 26: 318-326.

Ikemoto, T., T. Kunito, H. Tanaka, N. Baba, N. Miyazaki, and S. Tanabe. 2005. Detoxification Mechanism of Heavy Metals in Marine Mammals and Seabirds: Interaction of Selenium with Mercury, Silver, Copper, Zinc, and Cadmium in Liver. Archives of Environmental Contaminants and Toxicology 47: 402-413.

Jeppesen, C., M.E. Jørgensen, and P. Bjerregaard. 2012. Assessment of Consumption of Marine Food in Greenland by a Food Frequency Questionnaire and Biomarkers. International Journal of Circumpolar Health 71: 18361.

Koeman, J.H., W.S.M. van de Ven, J.J.M. de Goeij, P.S. Tjioe, and J.L. van Haaften. 1975. Mercury and Selenium in Marine Mammals and Birds. Science of the Total Environment 3: 279-287.

Larsen. T.L.J. 2017. The Association Between Whole Blood Mercury and the Risk of Developing CVD Among the Greenlandic Population. HEL-3950 Master's Thesis in Public Health, The Arctic University of Norway. May 2017. 50 pp. https://munin. uit.no/bitstream/handle/10037/11339/thesis.pdf?sequence= 2\&isAllowed $=\mathrm{y}$.

Letcher, R.J., J.O. Bustnes, R. Dietz, B.M. Jenssen, E.H. Jørgensen, C. Sonne, J. Verreault, M.M. Vijayan, et al. 2010. Effects Assessment of Persistent Organohalogen Contaminants in Arctic Wildlife and Fish. Science of the Total Environment 408: 2995-3043.

Leth, P.M. 2014. Botulism in Greenland. Forensic Science International 238: e1-e2.

Lindberg, S.E., S. Brooks, C.J. Lin, K. Scott, T. Meyers, L. Chambers, M. Landis, and R. Stevens. 2001. Formation of Reactive Gaseous Mercury in the Arctic: Evidence of Oxidation of $\mathrm{Hg}^{0}$ to Gas-Phase $\mathrm{Hg}$-II Compounds after Arctic Sunrise. Water, Air, \& Soil Pollution: Focus 1: 295-302.

Loutfy, M.R., J.W. Austin, B. Blanchfield, and I.W. Fong. 2003. An Outbreak of Foodborne Botulism in Ontario. Canadian Journal of Infectious Diseases 14: 206-209. https://doi.org/10.1155/ 2003/601525.

Lu, J.Y., W.H. Schroeder, L. Barrie, A. Steffen, H. Welch, K. Martin, L. Lockhart, R.V. Hunt, et al. 2001. Magnification of Atmospheric Mercury Deposition to Polar Regions in Springtime: the Link to Tropospheric Ozone Depletion Chemistry. Geophysical Research Letters 28: 3219-3222.

Miller, L.G. 1975. Observations on the Distribution and Ecology of Clostridium botulinum Type E in Alaska. Canadian Journal of Microbiology 21: 920-926.

Minamata Convention. 2017. http://www.mercuryconvention.org.
Mori, N., M. Yamamoto, E. Tsukada, T. Yokooji, N. Matsumura, M. Sasaki, and T. Murakami. 2012. Comparison of In Vivo with In Vitro Pharmacokinetics of Mercury Between Methylmercury Chloride and Methylmercury Cysteine Using Rats and $\mathrm{CaCo} 2$ Cells. Archives of Environmental Contaminants and Toxicology 63: 628-636.

O'Hara, T.M., and P.R. Becker. 2003. Persistent Organic Contaminants in Arctic Marine Mammals. In Toxicology of Marine Mammals, ed. J.G. Vos, G.D. Bossart, M. Fournier, and T.J. O'Shea, 168-205. London: Taylor \& Francis Publishers.

Paci, J.C.D, C. Dikson, S. Nickels, L. Chan, and C. Furgal. 2004. Food Security of Northern Indigenous Peoples in a Time of Uncertainty. In 3rd Northern Research Forum Open Meeting. Yellowknife, Canada.

Piniarneq. 2015. Data on the Greenlandic Hunt. Ministry of Fisheries \& Hunting, Government of Greenland.

Power, E.M. 2008. Conceptualizing Food Security for Aboriginal People in Canada. Canadian Journal of Public Health 99: 95-97.

R Core Team. 2016. R: A Language and Environment for Statistical Computing. Vienna: R Foundation for Statistical Computing.

Rigét, F.F., B.M. Braune, A. Bignert, S. Wilson, J. Aars, E.W. Born, M. Dam, R. Dietz, et al. 2011. Temporal Trends of Hg in Arctic Biota, An Update. Science of the Total Environment 409: 3520-3526.

Rigét, F.F., R. Bossi, C. Sonne, K. Vorkamp, and R. Dietz. 2013. Trends of Perfuorochemicals in Greenland Ringed Seals and Polar Bears from Greenland: Indications of Beginning to Decreasing Trends. Chemosphere 93: 1607-1614.

Rigét, F.F., K. Vorkamp, R. Bossi, C. Sonne, R.J. Letcher, and R. Dietz. 2015. Twenty Years of Monitoring of Persistent Organic Pollutants in Greenland Biota: A Review. Environmental Pollution 217: 114-123.

Scheuhammer, A.M., A.H.K. Wong, and D. Bond. 1998. Mercury and Selenium Accumulation in Common Loons (Gavia immer) and Common Mergansers (Mergus merganser) from Eastern Canada. Environmental Toxicology and Chemistry 17: 197-201.

Scheuhammer, A.M., N. Basu, N.M. Burgess, J.E. Elliott, G.D. Campbell, M. Wayland, L. Champoux, and J. Rodrigue. 2008. Relationships Among Mercury, Selenium, and Neurochemical Parameters in Common Loons (Gavia immer) and Bald Eagles (Haliaeetus leucocephalus). Ecotoxicology 17: 93-101.

Sonne, C., L. Bach, J. Søndergaard, F.F. Rigét, R. Dietz, A. Mosbech, P.S. Leifsson, and K. Gustavson. 2014. Evaluation of the Use of Common Sculpin (Myoxocephalus scorpius) Organ Histology as Bioindicator for Element Exposure in the Fjord of the Mining Area Maarmorilik, West Greenland. Environmental Research 133C: $304-311$.

Stockholm Convention. 2017. http://chm.pops.int/default.aspx.

Streets, D.G., Z. Qiang, and Y. Wu. 2009. Projections of Global Mercury Emissions in 2050. Environmental Science and Technology 43: 2983-2988.

Søndergaard, J., G. Asmund, P. Johansen, and F.F. Rigét. 2011. LongTerm Response of an Arctic Fjord System to Lead-Zinc Mining and Submarine Disposal of Mine Waste (Maarmorilik, West Greenland). Marine Environmental Research 71: 331-341.

Sørensen, H.C., K. Albøge, and J.C. Misfeldt. 1993. Botulism in Ammassalik. Ugeskrift for Lager 155: 108-109.

US Environmental Protection Agency. 1997. Mercury Study Report to Congress. Volume VII: Characterization of Human Health and Wildlife Risks from Mercury Exposure in the United States, EPA-452/R-97-009.

Vibe, C. 1950. The Marine Mammals and the Marine Fauna in the Thule District (Northwest Greenland) with Observations on Ice Conditions in 1939-41. Meddelelser om Gronland 150: 16-17. 
Wagemann, R., E. Trebacz, G. Boila, and W.L. Lockhart. 1998. Methylmercury and Total Mercury in Tissues of Arctic Marine Mammals. Science of the Total Environment 218: 19-31.

Wein, E.E., M.M. Freeman, and J.C. Makus. 1996. Use of and Preference for Traditional Foods Among the Belcher Island Inuit. Arctic 49: 256-264.

Wesche, S.D., and H.M. Chan. 2010. Adapting to the Impacts of Climate Change on Food Security Among Inuit in the Western Canadian Arctic. EcoHealth 7: 361-373.

WHO. 1993. Environmental Health Criteria 101: Methylmercury. Geneva: World Health Organization.

Woshner, V.M., T.M. O'Hara, G.R. Bratton, R.S. Suydam, and V.R. Beasley. 2001a. Concentrations and Interactions of Selected Essential and Non-essential Elements in Bowhead and Beluga Whales of Arctic Alaska. Journal of Wildlife Diseases 37: 693-710.

Woshner, V.M., T.M. O'Hara, G.R. Bratton, and V.R. Beasley. 2001b. Concentrations and Interactions of Selected Essential and Non-essential Elements in Ringed Seals and Polar Bears of Arctic Alaska. Journal of Wildlife Diseases 37: 711-721.

Woshner, V.M., K. Knott, R. Wells, C. Willetto, R. Swor, and T. O'Hara. 2008. Mercury and Selenium in Blood and Epidermis of Bottlenose Dolphins (Tursiops truncatus) from Sarasota Bay, Florida: Interaction and Relevance to Life History and Hematologic Parameters. EcoHealth 5: 1-11.

\section{AUTHOR BIOGRAPHIES}

Rune Dietz $(\square)$ D.Sc. is a professor at the Aarhus University, Department of Bioscience. His research interests include impacts of contaminant studies as well as tracking and population studies of marine mammals within the Arctic and temperate regions.

Address: Arctic Research Centre, Department of Bioscience, Aarhus University, Frederiksborgvej 399, 4000 Roskilde, Denmark.

e-mail: rdi@bios.au.dk
Anders Mosbech Ph.D. is a senior researcher at the Aarhus University, Department of Bioscience. His research interests include impacts of industrial activities on nature and environment in the Arctic and seabird ecology.

Address: Arctic Research Centre, Department of Bioscience, Aarhus University, Frederiksborgvej 399, 4000 Roskilde, Denmark.

e-mail: amo@bios.au.dk

Janne Flora Ph.D. is a postdoctoral researcher at the University of Copenhagen, Department of Anthropology. Her research interests include kindship, loneliness, suicide, and reincarnation, to migration and education, research methods, and collaboration.

Address: Department of Anthropology, University of Copenhagen, Øster Farimagsgade 5, 1353 Copenhagen K, Denmark.

e-mail: jakf@bios.au.dk

Igor Eulaers Ph.D. is a postdoctoral researcher at the Aarhus University, Department of Bioscience. His research interests include spatiotemporal sources and intensities of environmental stressors in Arctic and temperate food webs, including humans.

Address: Arctic Research Centre, Department of Bioscience, Aarhus University, Frederiksborgvej 399, 4000 Roskilde, Denmark.

e-mail: ie@bios.au.dk 